\title{
A NEW SPECIES OF ORTHAEA, A NEOTROPICAL MYODOCHINE GENUS WITH AN UNUSUAL HABITAT (HEMIPTERA: LYGAEIDAE: RHYPAROCHROMINAE)*
}

\author{
BY B. J. HARRINGTON \\ Department of Entomology, University of Wisconsin \\ Madison, Wisconsin 53706
}

The genus Orthaea, as described by Dallas (1852), was monotypic, with $O$. consuta the type species, and was treated by Stål (1874) as a subgenus of Pamera (Say, 1832). In 1914, Van Duzee argued against the use of the generic name Pamera, which Say (1832) had merely employed in a faunal list with no type or original species given, and suggested Orthaea as the valid generic name for a growing assemblage of myodochine species. In his subsequent catalogue of Hemiptera (Van Duzee, 1917) Pamera Stål (nec Say, 1832) 1874, Plociomerus A \& S 1843, Gyndes Stål 1862, and Diplonotus Stål 1872 were listed as synonyms of Orthaea, which generally persisted as the name employed for the group in question until Barber (1939) synonymized it with Pachybrachius (Hahn, 1826). Harrington's 1980 monograph of the tribe Myodochini recognized the large, catch-all genus Pachybrachius as polyphyletic, including several genera and representing separate lineages involving three of the four male genitalic types for the tribe. In that study (Harrington, 1980), the genus Orthaea, with genitalic Type IV, was resurrected from synonymy with Pachybrachius and noted to include the type species $O$. consuta and one other species, Orthaea procincta (Breddin) (1901).

The present paper describes a new species, Orthaea alveusincola, and provides features to distinguish it and the other two known species from each other. Details of the habitat in which the type series was collected are provided since this genus apparently occupies a niche unique for members of the tribe Myodochini.

All measurements in the following description are in millimeters and the Villalobos color chart (Palmer, 1962) has been used as a standard.

*Manuscript received by the editor September 2, 1986. 
Orthaea alveusincola Harrington, new species (Figure 1)

Description. Head, anterior pronotal lobe including collar, and scutellum sooty black. Posterior pronotal lobe, background color of clavus and corium, and majority of hemelytral membrane blackish brown; posterior pronotal lobe subtly lighter, grading toward light chestnut on humeral angles. A pair of small maculae on either side of midline on anterior half of posterior pronotal lobe, anterior onehalf of corial margin of clavus, adjacent base of corium, an elongate macula midlength along claval margin of corium, lateral corial margin except for apical corial angle, an elongate macula running just inside and extending less than half the length membranal margin of corium (forming a V-shape with the line-like pale lateral corial margin), and a small macula on hemelytral membrane adjacent to apical corial angle pale, between tawny and buffy yellow. A small diffuse area between cream and pale gray marking the posterior margin of the hemelytral membrane medially. Antennal segment I, distal onefourth of segment II, distal one-half of segment III, and extreme proximal portion and distal one-fourth of segment IV dark, fuscous tinged with chestnut. Femora of all three pairs of legs pale cream basally grading to between fuscous and tawny; the extent of the dark area greatest on the forelegs, covering almost three-fourths their length. Tibiae light tawny with distal ends fuscous. Tarsi with segments I and II light tawny and segment III darker. Abdomen laterally and ventrally dark chestnut, except pygophore dark tawny.

Legs, antennae, and labium smooth; antennae with short hairs and legs and labium with sparse elongate hairs. Meso-and metatibae also with bristles along full length. Head subshining with microrugosity and numerous short, recumbent, anteriorly directed hairs. Pronotum pruinose and with fine recumbent hairs. Collar of anterior pronotal lobe and posterior pronotal lobe prominently punctate; punctures present but smaller, sparse and very shallow on anterior lobe. Scutellum pruinose, punctate, and clothed with fine hairs. Hemelytra subshining with sparse hairs emerging from punctures. Clavus with punctation in three regular rows plus an incomplete fourth. Corium with a regular row of punctures along claval suture and another parallel row along cubitus; other claval punctation randomly distributed. Abdomen ventrally and laterally subshining, clothed with numerous fine recumbent hairs. 


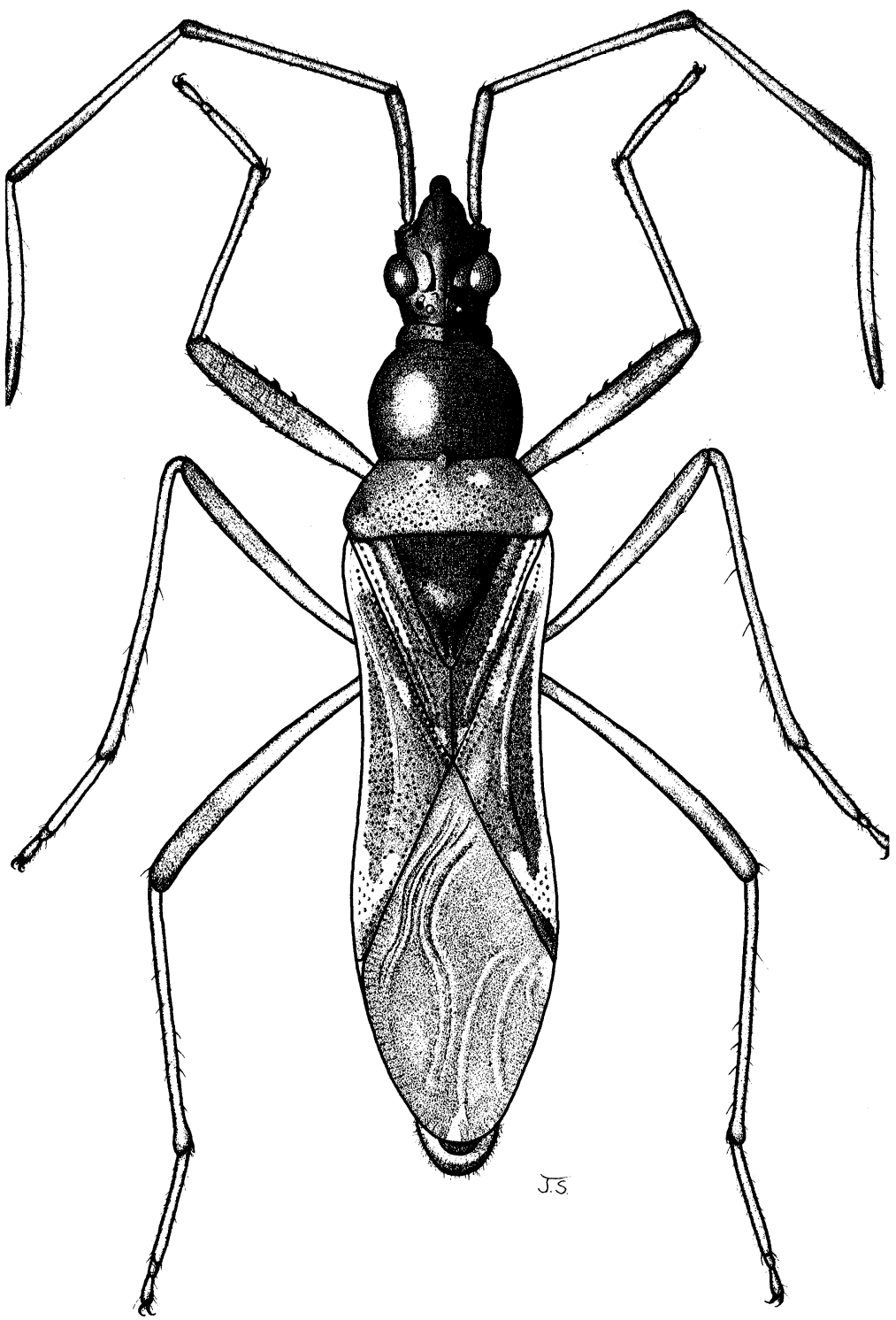

Fig. 1. Orthaea alveusincola Harrington, new species, holotype, dorsal view 
Head barely declivent anteriorly; somewhat prolonged in postocular region, but not constricted to form a neck. Tylus not attaining midlength on antennal segment I. Vertex flattened, slightly depressed before ocelli. Ocelli behind hind margin of eyes. Eyes rounded. Length of head 1.40; postocular length 0.30; width across eyes 1.10; interocular distance 0.52 . Anterior pronotal lobe rounded; anterior margin with a distinct band-like collar. Transverse pronotal impression well demarked and complete save for a narrow, median, dull carina. Posterior pronotal margin straight across base of scutellum. Humeral angles truncate, rounded. Length anterior pronotal lobe 1.22; width 1.38; width transverse impression 1.28; length posterior pronotal lobe 0.80 ; width across humeral angles 1.98 . Length scutellum 1.20; width 1.04. Hemelytra not quite attaining end of abdomen; rounded rim of pygophore visible posteriorly beyond hemelytral membrane. Lateral corial margins vaguely sinuate at level of claval commissure. Length corium 2.06; midline distance apex corium to apex membrane 3.04 ; length claval commissure 0.82 ; midline distance apex clavus to apex corium 1.82. Labium attaining anterior margin of metacoxal cavities. Length labial segments I 1.20 , II 1.30 , III 1.08 , IV 0.58 . Bucculae short, projecting anteriorly around base of labium; buccular juncture broadly V-shaped and occurring at level of antenniferous tubercles. Antennae slender and extremely elongate; segment IV fusiform and slightly curving. Length antennal segments I 1.32, II 2.22, III 2.14, IV 2.30. Legs elongate, slender. Fore femur slightly incrassate with spines double ranked, the anterior row extending proximad two-thirds the femoral length. Middle one-half or more of fore tibia bearing a single row of small spines. Mesofemur with a single row of spines on anterior surface. Mesepimeron barely emergent. Metathoracic scent gland auricle strongly elevated from pleural surface. Total length 8.98.

Holotype. Panama: $\hat{\jmath}$, La Mesa above El Valle, 13-I-1974, B. J. Harrington and J. A. Slater. In American Museum of Natural History, New York.

Paratypes. $7 \hat{\jmath}, 10 \%$, Same data as holotype. In American Museum of Natural History, New York; United States National Museum of Natural History, Washington; British Museum (Natural History), London and private collections of P. D. Ashlock, B. J. Harrington, and J. A. Slater. 
Variation. Female specimens lack spines on the foretibia and mesofemur. They also have the anterior pronotal lobe smaller, less rounded, and in a plane lower than that of the posterior pronotal lobes.

Etymology. This species is named $O$. alveusincola, "river-bed dweller", for the surprising habitat in which the type series was collected.

Diagnosis. O. alveusincola, consuta, and procincta can be distinguished from each other on the basis of their hemelytral color patterns. In alveusincola the lateral corial margin is narrowly pale complete to the subapical macula, which continues the pale area inward along the membranal margin in a characteristic V-shape. In both consuta and procincta the narrow pale area along the lateral corial margin extends posteriorly only about one-half to two-thirds the corial length stopping short of the pale subapical corial macula and that macula is broad and transverse, extending medially to the membranal margin instead of running at an angle as a stripe along the membranal margin. $O$. consuta lacks pale markings on the clavus, while both alveusincola and procincta have them, and $O$. consuta also lacks the distinctive pair of orange maculae on either side of midline on the anterior one-half of the posterior pronotal lobe that are present in the other two species. $O$. consuta and procincta have the lateral margins of the posterior pronotal lobe broadly marked with orange, contrasting with the dark background; in alveusincola these margins are not so distinctly marked and only vaguely, if at all, lighter than the background. O. procincta lacks foretibial and mesofemoral spines in the males as well as females, while alveusincola and consuta males have rows of spines in both areas.

Habitat. The type series of O. alveusincola was collected among rocks in the partially dry bed of a mountain or highland stream (approximate elevation $750 \mathrm{~m}$.) in Panama. The insects were most abundant in hollows and around rocks where seeds of an overhanging tree were concentrated. They ran rapidly, often entering the edges of trapped pools of water, and flew readily when pursued, indicating full macroptery consistent with the temporary nature of the habitat. Two series of $O$. procincta from Peru that were examined in this study each also have labels reporting collection in association with a rapid stream at high elevations (500 m. and $1600 \mathrm{~m}$.). 
One generally would not anticipate finding rhyparochromine Lygaeidae closely associated with a stream, since their diet of seeds would be expected to either rot or germinate on moist ground. Yet a highland stream, which can by flash flooding wash and concentrate seeds and then dry rapidly, would provide a very suitable habitat with a rich concentration of a seed resource to be exploited. Members of the genus Orthaea have apparently adapted to capitalize on this resource, since two of the three known species have been collected in such a habitat.

Currently, known distributions for the genus include $O$. consuta from British Guiana and Colombia, $O$. procincta from Ecuador, and $O$. alveusincola from Panama. As Orthaea is apparently a highland genus in an unexpected habitat and thus not commonly collected, it is quite likely that additional new neotropical species may be found, having evolved as montane isolates.

\section{SUMMARY}

A new species, Orthaea alveusincola, from Panama is described. Diagnostic features are presented to distinguish it and the other two species in the genus, $O$. consuta Dallas and $O$. procincta (Breddin). The type locality is described and the unusual river-bed habitat of the genus is discussed. A full dorsal view illustration of the holotype of $O$. alveusincola is provided.

\section{ACKNOWLEDGMENTS}

I thank Dr. H. Dodge Engleman of the Coco Solo Hospital, Panama Canal Zone, who was a generous host and collecting associate during a field trip to Panama. I appreciate the loan of specimens of described species by W. R. Dolling of the British Museum (Natural History), London and P. D. Ashlock of the Snow Entomological Museum, University of Kansas, Lawrence, KS. I thank Jeffrey Sternberg, University of Wisconsin, Madison for the excellent dorsal view illustration of the holotype. This research was supported by the College of Agricultural and Life Sciences, University of Wisconsin, Madison (Project No. 2578). 


\section{Literature Cited}

Barber, H. G. 1939. Scientific survey of Porto Rico and the Virgin Islands: Insects of Porto Rico and the Virgin Islands: Hemiptera-Heteroptera (excepting the Miridae and Corixidae). Sci. Surv. P. Rico 14: 3: 263-441.

Breddin, G. 1901. Neue neotropische Wanzen und Zirpen. Soc. Entomol. 16: 59.

Dallas, W. S. 1852. List of the specimens of Hemipterous insects in the collection of the British Museum. Part II. London: Taylor and Francis Inc. p. 580.

HaHN, C. W. 1826. Icones ad monographium Cimicum. Nurnberg: Lechner. 1: 18.

Harrington, B. J. 1980. A generic level revision and cladistic analysis of the Myodochini of the world (Hemiptera, Lygaeidae, Rhyparochrominae). Bull. Amer. Mus. Nat. Hist. 167:2: 45-116.

Palmer, R. S. 1962. Handbook of North American birds. Vol. I Loons through flamingos. Yale University Press, New Haven col. pl.

SAY, T. 1832. Descriptions of new species of Heteropterous Hemiptera of North America. New Harmony, Indiana. 1831: 16.

STÅL, C. 1874. Enumeratio Hemipterorum pt 4. K. svenska VetenskAkad. Handl. 12:1: 1-186.

Van Duzee, E. P. 1914. Nomenclatural and critical notes on Hemiptera. Canad. Entomol. 46: 377-389.

Van Duzee, E. P. 1917. Catalogue of the Hemiptera of America North of Mexico (excepting the Aphididae, Coccidae and Aleurodidae). University of California Press, Berkeley. p. 183. 

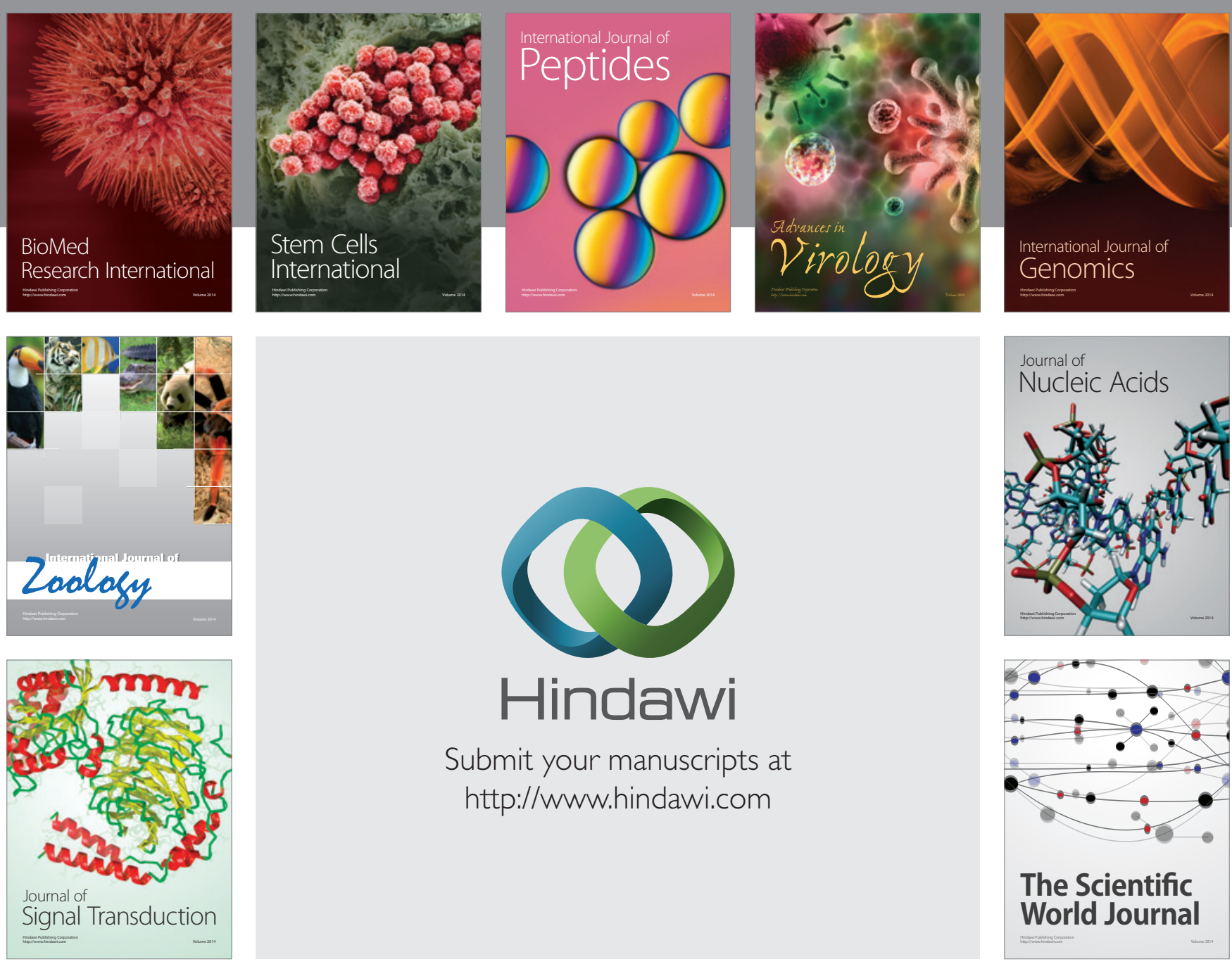

Submit your manuscripts at

http://www.hindawi.com
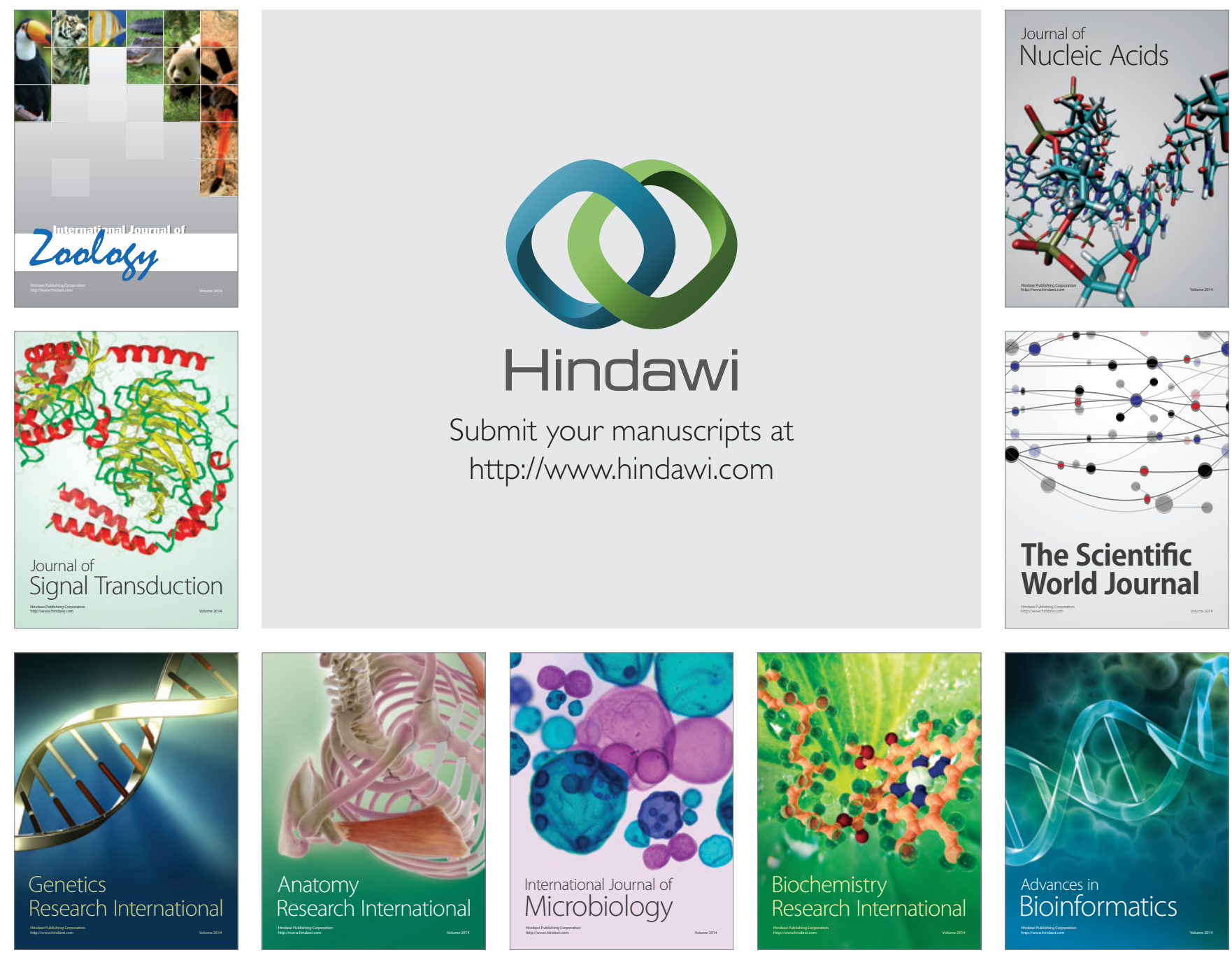

The Scientific World Journal
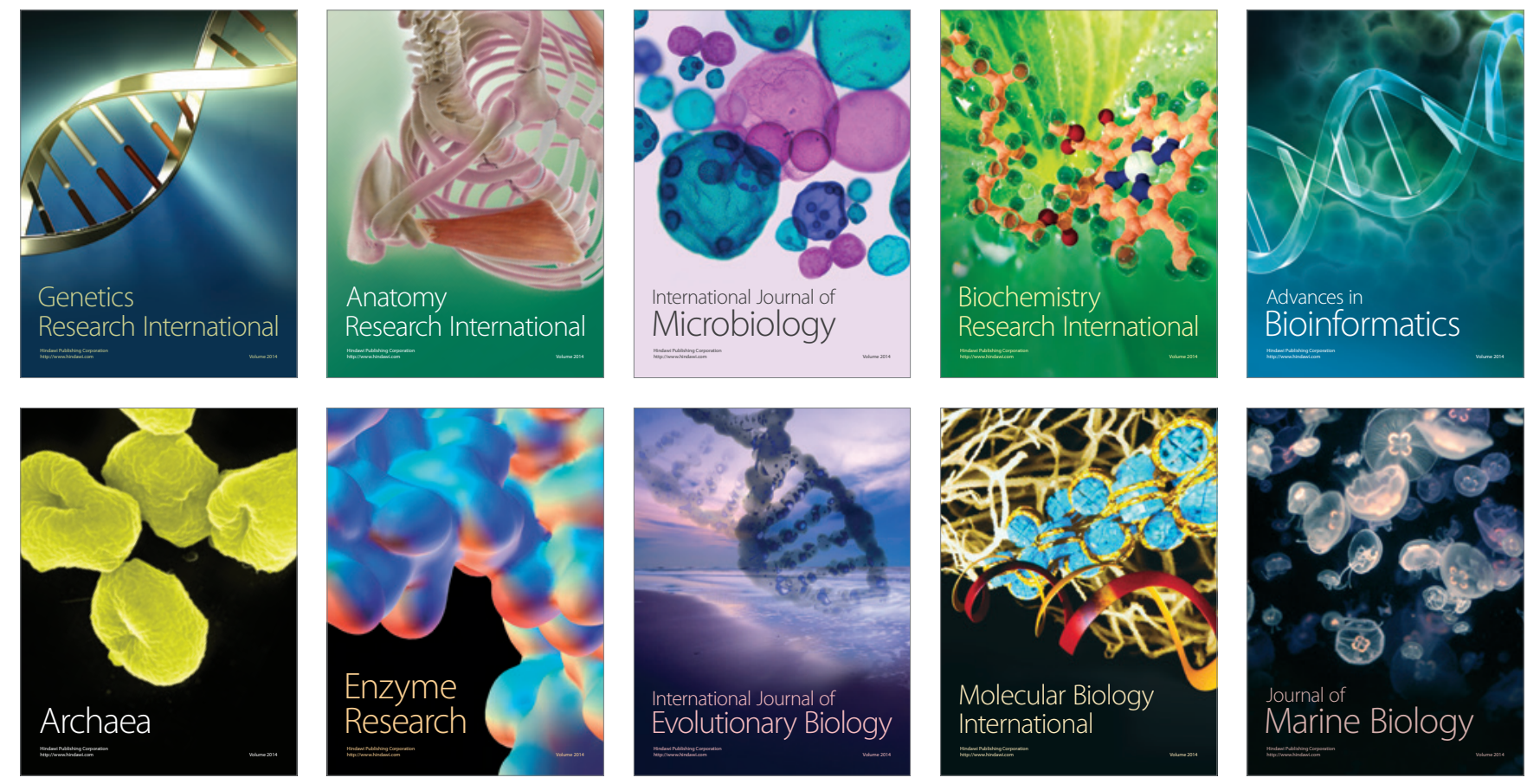